\begin{tabular}{ll}
\hline 薬 \\
\hline
\end{tabular}

\title{
Niceritrol を用いた顔面神経麻摩の治療成績
}

\author{
山際 幹和・久保 将彦・原田 輝彦・清水 猛史 \\ 林 秀俊・金 春順・坂倉 康夫
}

\section{Effect of Niceritrol Combined with Other \\ Drugs in the Treatment of Facial Palsy}

\author{
Mikikazu Yamagiwa, Masahiko Kubo, Teruhiko Harada, \\ Takeshi Shimizu, Hidetoshi Hayashi, Jin Chun Shun \\ and Yasuo Sakakura
}

(Mie University)

Niceritrol, a derivative of nicotinic acid, has been used in the treatment of atherosclerotic and obstructive vascular diseases. It was given to patients with facial palsy for 8 weeks or morc in combination with massive doses of ATP and/or steroids used during the initial 2 or 3 weeks.

1. Assessment by our Paralysis and Secondary Defect Score showed that the results could be classified as 'good' or better in $37.2 \%$ of the patients in 2 weeks, $54.2 \%$ in 4 weeks, $60.0 \%$ in 6 weeks and $68.5 \%$ in 8 weeks.

2. It was striking that 3 of 4 patients with Hunt's syndrome recovered completely within 4 wceks and one patient with severe paralysis for 20 years due to surgical trauma showed a fair recovery.

These results indicate that the combination of niceritrol and ATP and/or steroids is effective in the therapy of facial palsy.

Key words: niceritrol, facial palsy, therapy

緒言

顔面神経麻瘴の原因が何であれ，その保存的 治療に際して血管搪張作用を有する薬剂を用い ることは有意義であり, その使用頻度は高い。

Niceritrol は脂質代謝改善の目的で繁用され ている薬剤であるが ${ }^{122}$, 持続的で強い血管拡 張作用 ${ }^{3)}$ や，血小板凝集を抑制すること年5) か
ら, 耳鼻咽喉領域ではめまい疾患に対して応用 され，その有用性が報告されている ${ }^{6)}$.

今回, 我々はその作用機序より, Niceritrol は顔面神経麻痺に対しても充分有用性の期待で きる薬剤であると考え，それを組み入れた治療 を行った。 その結果, 幾分興味深い成績が得ら たので，その概略を報告する。 


\section{治療対象}

1983年10月より1986年 1 月までの間に, 三重 大学医学部附属病院耳鼻咽喉科で保存的治療を 行った顔面神経麻瘦患者35名を対象とした。年 齢は14〜83才（平均46.6土21.0才）に分布し，

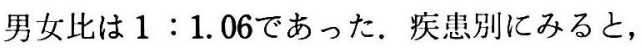
Bell 麻瘏 22 例, Hunt 症候群 6 例, その他 （術後性および外傷性麻痺）７例であった。

\section{治療方法}

治療楽剂として, 1 カプセル, あるいは 1 錠 中に Niceritrol 250mg を含有する Perycit ${ }^{\circledR}$ （三和化学研究所）を 1 回 2 カプセルあるいは 跎 1 日 3 回毎企後に連日 8 週間以上経口投与. し，原則として $2 ， 4 ， 6$ および 8 週目に効果 の判定を行った.

なお，当科では，顔面神経麻㽽の保存的治療 を行う場合には，副腎皮質ホルモン渐減療法上 A T P 大量療法 ${ }^{718)}$ 基本治療法としている. したがって, 多くの場合, Niceritrol はそれ らと併用投与されている.

\section{効果判定方法}

表情筋の運動状態を視診および筋電図検查に

表 I

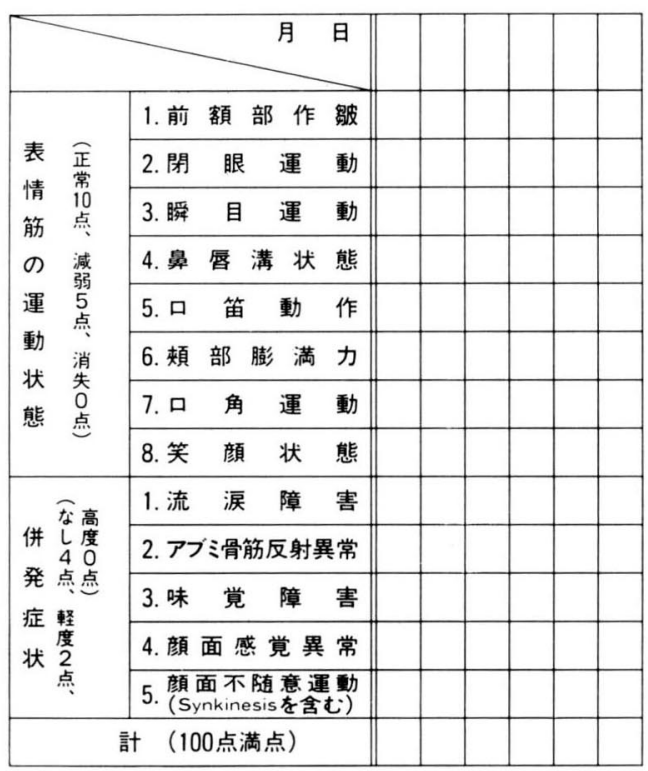

よって評価し，同時に併発症状の程度を考慮し たうえで, 表 1 に示した方法で数量化（顔面神 経麻䠋スコアー）し，それを治療効果判定資料 とした。

そして，治療効果の秤価は表 2 に示す 2 通り の方法で行った。

\section{治療成績}

図 1 は全35例の I 法による評価結果を示す. 不完全麻痺例や既治療で改善傾向にあった例む 含まれているため， Niceritrol 投与開始時（0 週）に既に有効あるいはやや有効の範疇に入っ ている例が40\%強あるが, 2 週目上り著効之判 定される例が出現し，4 週目の著効率は $48.5 \%$ になった６週目以降は幾分改善傾向の鈍化が 生じているが, 最終効果判定時点（8 週目）で は著効 $51.4 \%$, 有效 $17.1 \%$, やや有効 $17.1 \%$ と なった。

図 2 は各週におけるスコアーの平均士標準浞

表 2 治療効果の評価方法

\begin{tabular}{|c|c|}
\hline I）著 & 効：スコアーが90点以上 \\
\hline 有 & 効：スコアーが70点以上 90 点末満 \\
\hline $\begin{array}{l}\text { や } \\
\text { 無 }\end{array}$ & $\begin{array}{l}\text { 効：スコアーが50点以上70点末満 } \\
\text { 効：スコアーが50点末満 }\end{array}$ \\
\hline
\end{tabular}

II) 著明改善：スコアーが40点上改善

中等度改善：スコアーが20点以上40点末満改善 軽度改善：スコアーが10点以上20点末満改善 不変悪化：スコアーが10点末満改善および悪化

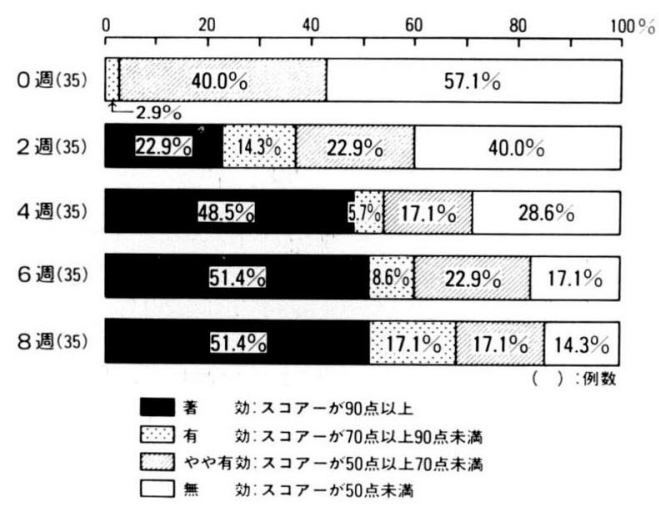

図 I 全症例の効果判定結果 
差を求めグラフ化したものである．Niceritrol 投与前の值に比べ 2 週目以降の值は推計学的に 有意に上昇している.

図 3 は川法による評価結果を示す。既に治療

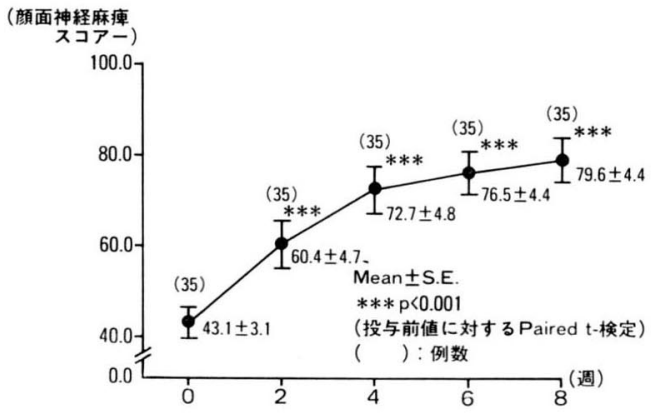

図 2 顔面神経麻瘏スコアー全症例の推秎

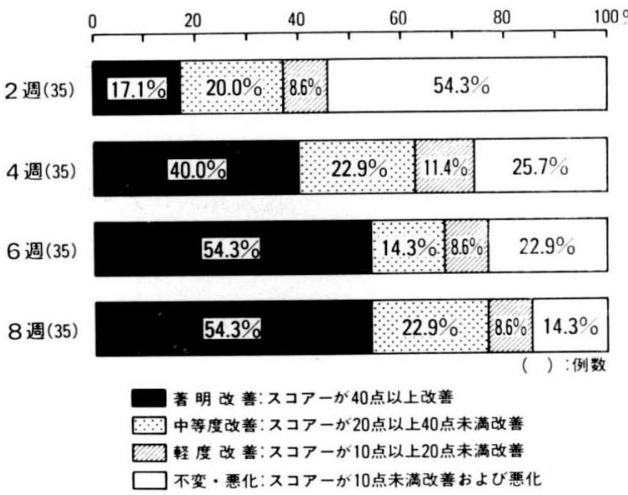

図 3 全症例の顔面神経麻瘦スコアーの改善度
開始時スコアーが60点以上あり, 治痛したにも 拘らず中等度改善と評価された例が 2 例あり， 幾分評価方法に問題はあるが，図のように 6 週 目まではスコアーは順調に改善している。

図 4 は発症より Niceritrol 投与開始までの 期間と治療成績につきみたものである，概して その期間が短い例ほど成績は良好であると言え るが，発症後 4 週以上経過していた例の中にも 治瘾した例や著しくスコアーが改善した例が認 められた。

図 5 は発症より Niceritrol 投与開始までの 期間とスコアーの改善度につきみたものであ る. 発症後 2 週未満の例での改善度は高く, 全 く無効に終わった例はみられなかった。それに

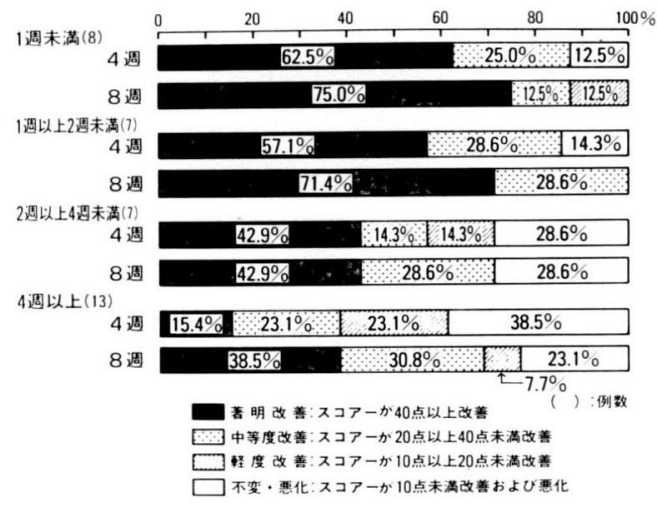

図 5 発病からペリシット投与開始までの期間別 にみた顔面神経麻盘スコアーの改善度
一発病より 2 週未满 (15例) -

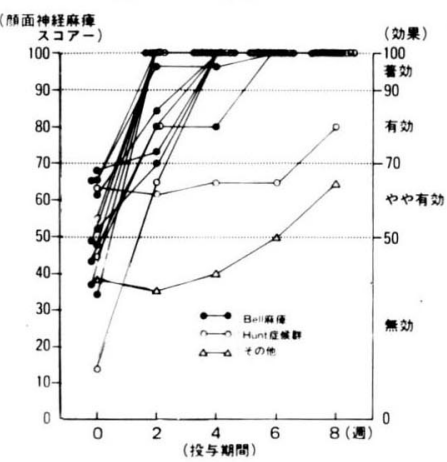

一発病より 2 週以上 4 週未满 (7例) -

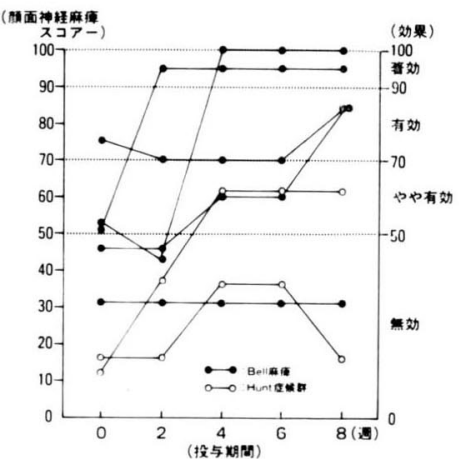

一病より 4 通以上 (13例) -

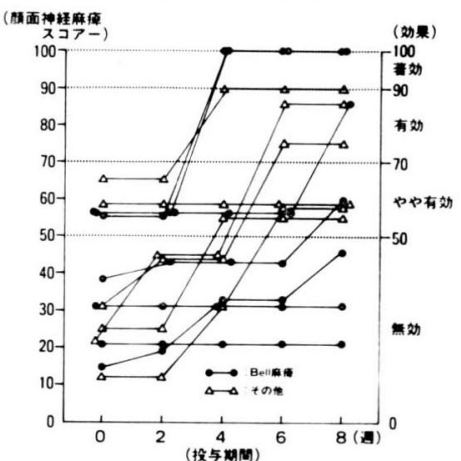

図 4 発病からペリシット投与開始までの期閒別にみた顔面神経麻痖スコアーの推移 
刘して， 2 週以上経過していた例では，著しく 改善した例があった反面無効に終わった例もか なりの㓶合で認められた。

図 6 は治療開始時スコアーが50点以上例とそ れ未満の例に 2 大别し治療後のスコア一の推移 をみたものである．前者の多く（93\%）は有効 以上の評価を得たが, 後者では著効十有効率は 50\%であり，無効に終わった例も25\%認められ た。しかしながら，スコアーの收善度をみる 上, 後者でむ著明な改善を示した例が少なくな く, 治㾍例 $(35 \%)$ 屯認められた。

図 7 は疾患別にみたスコアーの改善度を示 す. 概して難治である Hunt 症候群での改善 度が高いことが目立ち，その治瘜率（50\%）も 低くはなかった（図 4，6）。また，術後性お よび外偍性（その他）森猈例では 4 週目に比へ 8 週目で著明改善例が急增したのが特徴的であ った.

図 8 は併用治療法別にみたスコアーの推移を 亦す. 患者の背景に相違があり厳密な意味での 比較はできないが，A T P 大量療法十ステロイ

一 治療開始時スコアー50点以上 (15例) -

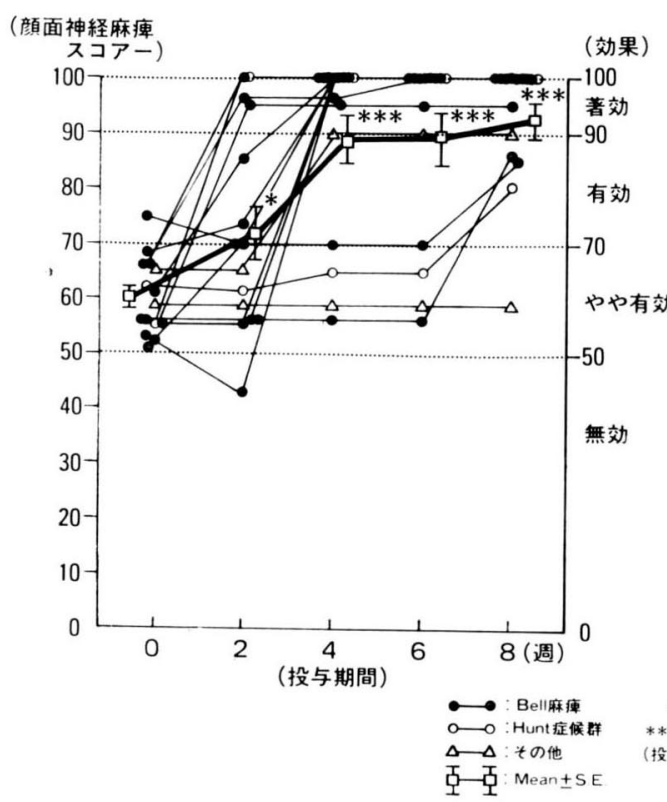

図 6 治療開始時スコアー別にみた顔面神経麻瘦スコアーの推移
ド療法やＡＴＰ大量療法に Niceritrol を併用 投にした例で著効率が高かった。ステロイド療 法と Niceritrol を併用した 4 例の改善度は高 かったが，著効之評価された例はなかった。そ の他の療法に Niceritrol を併用した10例の中 には比較的陳旧例が多かったが，治㦄した例や 著明改善例屯認められた。

図 9 は併用治療法别にみたスコアーの改善度

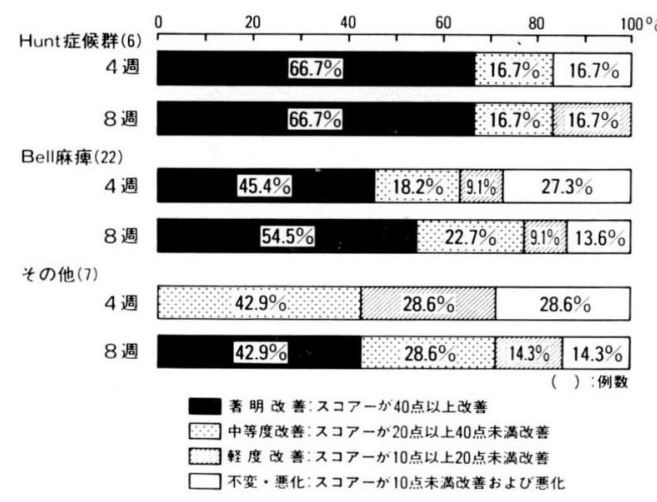

図 7 彰断名別にみた顔面神経麻瘏スコアーの改善度

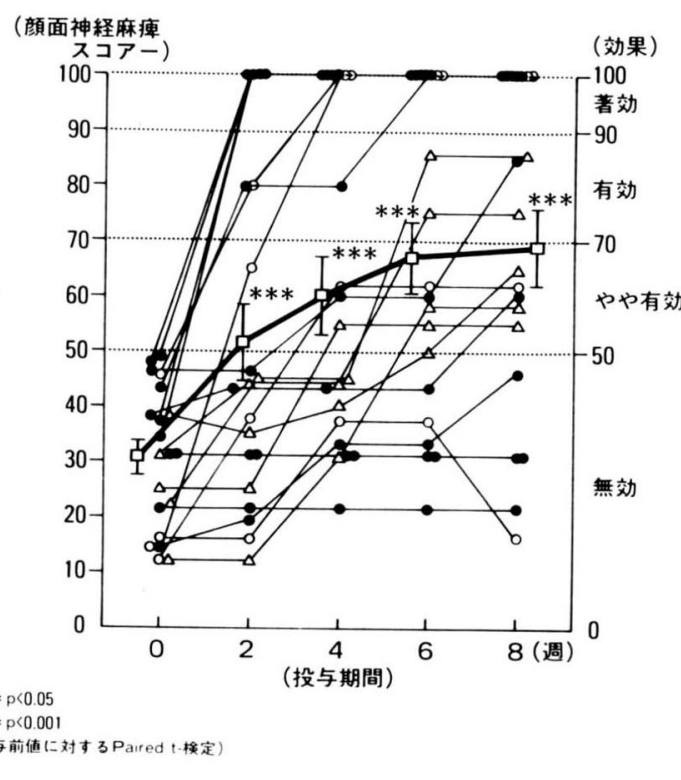




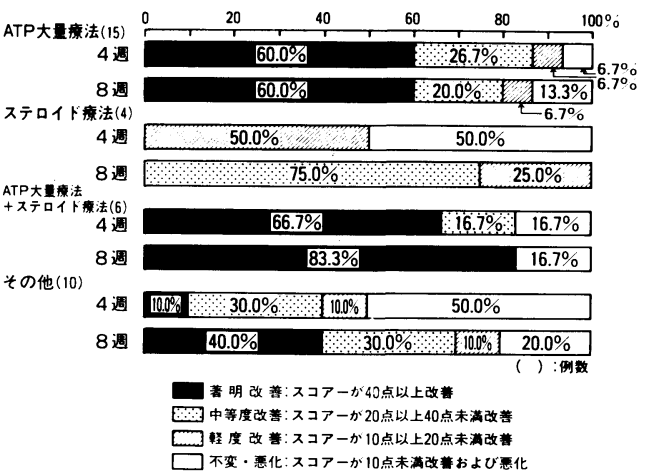

図 9 併用治療法別にみた顔面神経麻焷スコアー の改善度

- ATP大贯费法 (15例) -

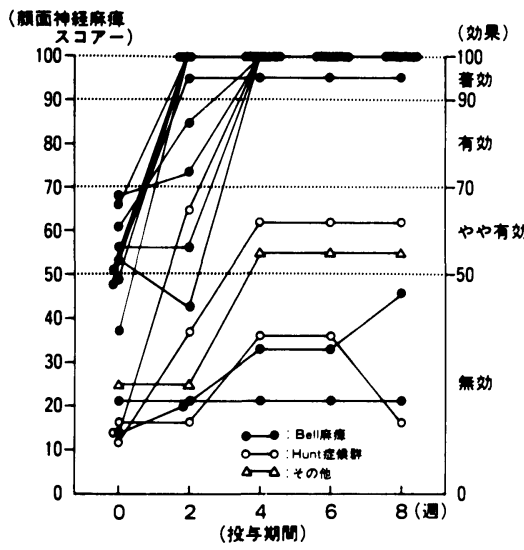

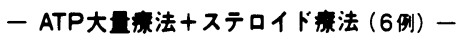

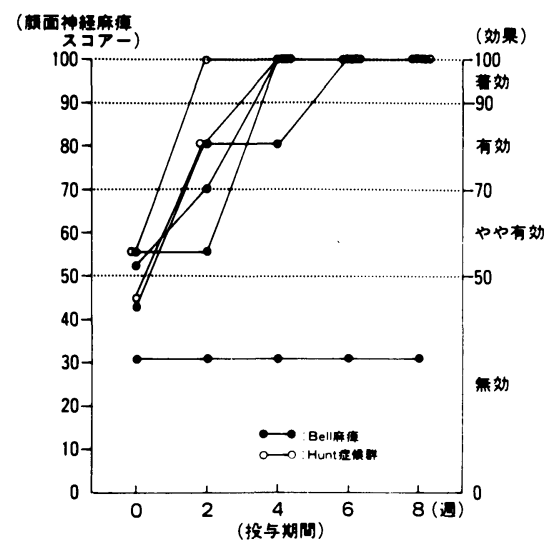

を示す。A T P大量療法あるいはとれにステロ イド療法を併用した例に Niceritrol を併用投 与した際の改善度が高かった。

全35例中 2 例にニコチン酸の末梢血管拡張作 用によると考えられるフラッシング症状（皮膚 の発赤・紅潮・熱感・瘙㾕感など）が出現した が，服薬の続行は可能であった。ただし，他に 2 例同症状のために服薬の中止を希望し服薬後 早剘に休楽を余儀なくされた例があり，副作用 発現率は $10.8 \%$ （4/37）であった。

\section{症例}

陳旧例であったにも拘らずA T P 大量療法を

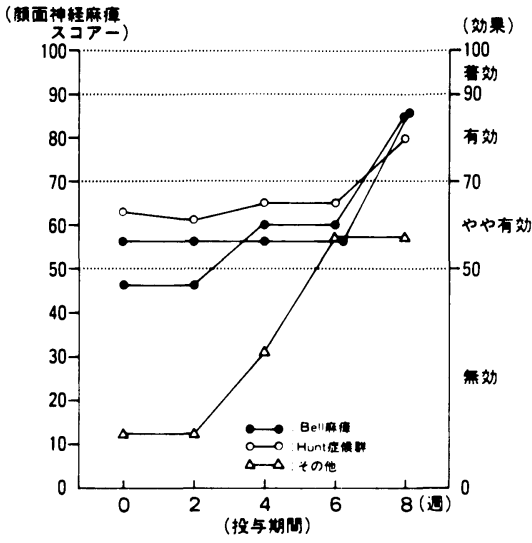

一 その他の症法 (10例) -

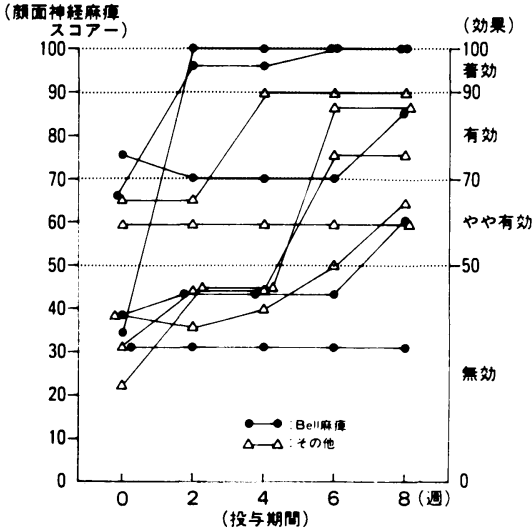

図 8 併用治療法別にみた顔面神経麻瘢スコアーの推移 
行ったうえで Niceritrol を併用投与したとこ ろ，自他覚的に顕著に改善した 1 例を経験した ので報告する.

症例 : 20才, 女,

初晾：1985年10月 7 日.

現病歴：生後 4 ケ月の将, 右耳下腺部任管腫 の診断のもとに摘出術を受け，以来，右顔西神 経㑣舫を来す。18才の侍, 某大学病院耳鼻咽 喉科を受診し，神経興奮性検査（NE T) を受 け興奮性が僅かに残存していることを指摘され た. 20才の時, 当科看謢実兒の際, 筋電図検查 をすすめられ，受けたところ，口輪筋に散発的 に motor unit action potential が見出され, 回復が期待されたため，治療を受けることにな った。

治療方法および経過：初診より約 1 ケ月間, 理学療法を行ったが無効に終わった。学業の都 合むあり，1986年 1 月 13 日より A T P 大量療 法7) 2 週間行い, Perycit ${ }^{\circledR}$ Capsule を 1 回 2 カプセル 1 日 3 回毎食後に11週間投与した. その結果，顔面神経麻䠋スコアーは25から60に 改善し，筋電図検查所見も明らかに改善した （図10）。その後転医し，血管拢張剂とビタミン Bn製剂を服用し理学療法を続けている。1986年 9 月現在, 顔面神経麻盘スコアーは65である.
安静状態では口角下垂が目立ち, 病的共同運動 屯認められるが，治療効果が顕著に現れた陳旧 性林㔣の 1 例である。

\section{考察}

顔面神経麻瘏の治療方法は, 保存的治療と手 術的治療の 2 つに大別されるが，外傷性麻瘏は ともかくとして, Bell 麻瘏や Hunt 症候群に 対してはどちらの才法を用いて治療を行ったおj がいいかは意見の分れるところである。

我々は, 原則として, 受傷直後に発症し, 脱 神経状態にある例や術中顔画神経が損傷された 例を除き，顔面神経林䁬に対しては外来通院の 形で保存的治療を行っている。 その埸合，基本 的治療としては，副腎皮質ホルモン漱減療法や A T P 大量療法あるいはその双才をを併用した治 療を行い，随時，複合ビタミン剂，ビタミン $\mathrm{B}_{12}$ 製剂，A T P 製剂，血管搪張剂などを経口的に 投与している。副腎皮質ホルモン漸減療法や $\mathrm{A}$ $\mathrm{T} P$ 大量療法を行う期間は概ね 2 〜 週間であ り，その後は先にあげた薬剂を経口的に継続投 与することになる。したがって，本疾患の治療 効果をあげるうえで，それらの楽剤をいかに選 択するかむまた重要な問題となる。 その意味 で，今回は，強力な血管昖張作用を有するとさ れる Niceritrol を組み入れた保存的治療の効

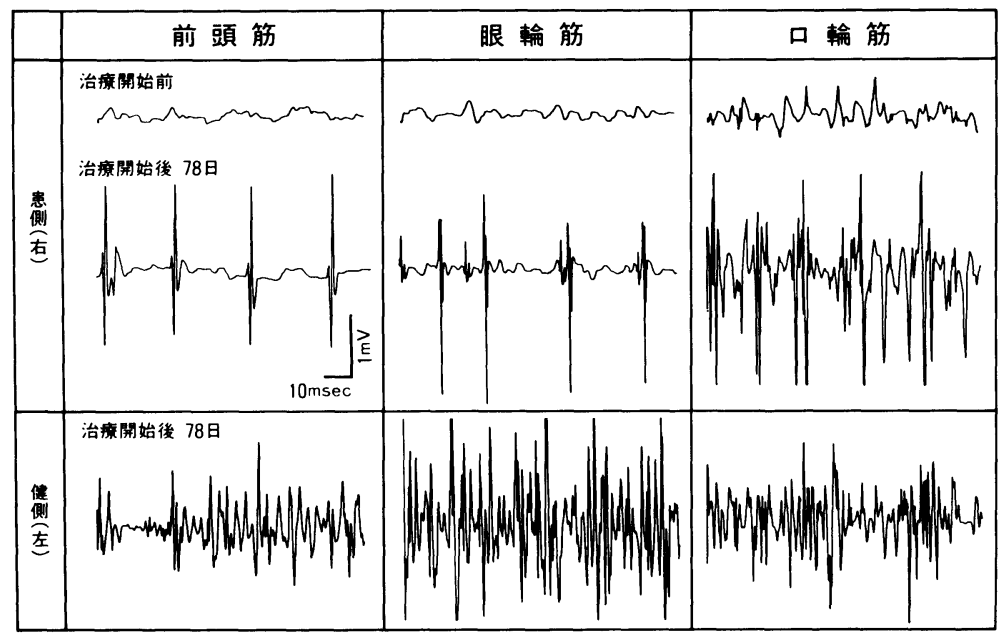

図10 筋電図検査成績 20才，女) 
果を検討した。

顔面神経麻瘏に対する薬物療法の効果を判定 するに際して，まず問題となることは，はたし て薬剤の投与がどの程度麻瘦の改善に寄与する かという点である。ことに Bell 麻痖の場合, 70\%を越える自然治癒があることが報告されて いる ことから，それよりあ推計学的に有意に 良好な薬物治療成績を出すことは至難の技であ る.ただ，Bell 麻瘏例に対しては，発症後早 期に積極的な薬物治療を行えば，その方法のい かんに拘らず，自然治癒率よりは高い治癒率が 得られることは確かであり, 我々が以前に集計 した発症後 3 週以内の Bell 麻瘏例の治癒率は

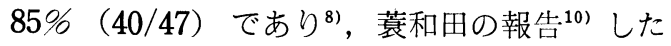
発症後10日以内の Bell 麻痵例のそれは $92 \%$ （68/74）と高い。また，陳旧例之言えるような 例であっても，それらの治療で顕著に改善する 例があり，安易に自然治癒に期待すべきでない ことは明白である。 今回, 我々が Niceritrol を併用して治療した発症後 2 週未満の Bell 麻 舫例10例は効果判定期間（8週）内に全て治癒 している（図4）こともこれを裏付けていると ともに Niceritrol の併用効果の有用性を物語 っている。

我々は, ヘルペスを伴わない例でも，林瘏側 の耳介等に有痛性の発赤・腫脹を伴った顔面神 経麻舫例は Hunt 症候群と分類して治療して いる．今までの我々の集計では，それらの治痿 率はたとえ発症後早期に治療を開始した場合で 屯低く，40\%前後 ${ }^{811)}$ であり，治療上難啮する 例が多かった。それに対して，今回発症後 2 週 未満に治療を開始した Hunt 症候群の 4 例中 3 例が 4 週以内に治痛した（図 4 ）乙とは極め て興味深く思われた。乙れもまた極めて少数例 であるため明言はできないが， Niceritrol の 有用性を示す成績かと思われる。

近年，極めて注目を集めている Bell 麻痺の 治療法として, Stennert の治療方法 ${ }^{12)}$ があ る。それは，低分子デキストラン， Pentoxifylline および Cortisoneを最初の10日間入
院のうえ16あるいは 8 時間かけて点滴静注し, その後は外来通院のうえで Cortisone を内服 させる方法である。その治療方法により，発症 後 20 日以内に受診した 132 例のうち $94 \%$ が治癒 したことが報告されている。我が国では, Pentoxifylline は注射薬としては販売されていな いが，今回検討した Niceritrol はそれに極め て類似した作用を有する薬剤であり，しかもそ の作用が強力であるとされている，したがっ て, Pentoxifylline に代えて Niceritrol を 組み入れた形で Stennert の治療方法を追試し てみることも興味深く, 今後の検討課題とした い.

顔面神経麻痖の治療に際して，興味の持たれ る点のひとつとして, 発症後かなりの日数がた ち，それ以上の改善が期待できないと考えられ るような例でも，改善する例があることであ る ${ }^{8)}$. 今回供筧した 1 例もそのような例であ り，発症後 20 年を経ていたにも拘らず自・他覚 的に顕著に改善した。本例は，顔面神経麻痺の 場合は発症後長期間を経ていても，脱神経に至 っていなければ，積極的に加療を行ってみるて とも無意味ではないととを示唆している．当 然, 治療効果に限界はあるものと思われるが, このような例に対する血管拡張剂の効果は予想 以上のあのである可能性がある.

冒頭に述べたように，Niceritrol は脂質代 謝改善の目的で繁用されているニコチン酸誘導 体である，その有する作用機序をみると，めま い疾患に対しては当然使用してしかるべき薬剂 である ${ }^{6)}$. 今回検討した顔面神経麻痺に対して は勿論のとと，突発性難聴をはじめとする各種 神経障害に対しても充分効果が期待できる薬剂 である。また，副作用として取扱われているフ ラッシング症状はむしろ強力な血管搪張作:用の 証明であり，逆に言えば，その様な副作用が高 率に出現するような薬剂ほど期待できる薬剤で あると言えるかむ知れない。

\section{結語}

顔面神経麻痺患者 35 名（男性17名，女性18 
名，平均年齢 $46.6 \pm 21.0$ 才） に対して Niceritrol を併用した保存的治療を行い, 効果を検 討したところ以下の成績を得た。

1. 全35例の著効十有効率は, 2 週目で37. 2 \%, 4 週で54. $2 \%, 6$ 週目で $60.0 \%, 8$ 週目で $68.5 \%$ あ゙あった。

2. 概して発症より治療開始までの期間が短 い例, 治療開始時の麻瘴の程度が軽い例で治療 成績は良好であったが，陳旧例でも顕著に改善 した例が認められた。

3. 従来難治とされている Hunt 症候群の 治療成績も良好であった点が注目された。

4. 副作用としてのフラッシング症状が 10.8 \%の例で認められたが，他に問題となる副作用 は認められなかった。

Niceritrol 投与後比較的短期間内に効果を 判定したにあ拘らず，その効果は良好であり， 本剤は顔面神経麻瘏の保存的治療を行ううえで 重要な位置を占める薬剤であると結論した。

\section{参考文献}

1) 内藤周幸, 他：S K-1 の高脂 血症治療効果任対 する臨床的検討一二重盲検法によるクロフィブレ ートとの比較一．医学のあゆみ $102: 638 〜 668$, 1977.

2 ) 亀井文雄：高脂血症に対する Perycit の臨床的 検討. 䛦療と新薬 $18: 1281 \sim 1288 ， 1981$.

3) 林 元英, 他: Niceritrol の薬理学的研究（第 7 報）末梢血管拡張作用. 応用薬理 $24: 835$
842, 1982.

4) 浜崎智仁, 他 : ニセリトロールの抗血栓作用一プ ロスタグランディン代謝に及ぼす影響一。動脈硬 化 $10: 857 \sim 860,1982$.

5 ）永川祐三，他：動脈硬化性疾患における Niceritrol の血小板凝集能，血墏脂質に及ぼす影響に ついて. 動脈硬化 II：637〜644, 1983.

6 ）久保 武, 他：めまい疾患に対する二セリトロー ルの使用経験.耳鼻 $30 ： 57 〜 62,1984$.

7 ）石神寛通，他：急性感音性難聴に対する A T P大 量療法の効果一各種治療法との統計的比較検討 一. 耳鼻臨床 $69: 875 \sim 896,1976$.

8 ) 山際幹和, 他 : 顔面神経麻㿉の治療成績. 耳鼻臨 床 $74: 928 \sim 937,1981$.

9) May M and Taylor FH : Bell's palsy : Surgery based upon prognostic indicators and results. Laryngoscope 91:2092 2105, 1981.

10）㝨和田寛子：顔面神経麻痷の臨床的研究. 耳鼻臨 床 $62: 735 \sim 798,1965$.

11）大山 勝, 他：顔面神経麻幚に対する保存的療法 一過去 2 年間の臨床統計 と Coenzyme $\mathrm{Q}_{10}$ 使 用成績について一。 耳展 19:315〜322, 1976.

12) Stennert $\mathrm{E}:$ Pathomechanisms in cell metabolism : A key to treatment of Bell's palsy. Ann Otol Rhniol Laryrgol $90: 577 \sim 581$, 1981.

$$
\left.\begin{array}{l}
\text { 原稿採択 : 昭和 } 61 \text { 年 } 12 \text { 月 } 18 \text { 日 急載 } \\
\text { 別刷請求先 }: \text { 山際幹和 } \\
\text { 厂514 津市江戸橋二丁目 } 174 \\
\text { 三重大学医学部耳鼻咽喉科学教室 }
\end{array}\right)
$$

